Muji Astuti, Strategi Implementasi Green ... 121

DOI: https://doi.org/10.24843/MATRIK:JMBK.2018.v12.i02.p04

\title{
STRATEGI IMPLEMENTASI GREEN HUMAN RESOURCE MANAGEMENT PADA USAHA MIKRO, KECIL DAN MENENGAH (UMKM)
}

\author{
Mudji Astuti(1) \\ Hana Catur Wahyuni( ${ }^{(2)}$ \\ ${ }^{(1)}$ Prodi Manajemen, Universitas Muhammadiyah Sidoarjo \\ (2)Prodi Teknik Industri, Universitas Muhammadiyah Sidoarjo \\ email: hanacatur@umsida.ac.id
}

\begin{abstract}
ABSTRAK
Usaha Mikro Kecil dan Menengah (UMKM) adalah unsur ekonomi yang penting bagi pertumbuhan perekonomian masyarakat, dan merupakan salah satu jenis usaha yang mampu menyerap banyak tenaga kerja karena sifatnya yang padat karya. Tetapi, disisi lain tingkat kesadaran UMKM terhadap pengelolaan lingkungan perlu ditingkatnya. Hal tersebut yang melatar belakangi pentingnya implementasi green human resource management (green HRM) pada UMKM. Penelitian ini bertujuan untuk menentukan prioritas kriteria- kriteria green HRM pada UMKM dan perumusan langkah strategis dalam optimalisasi green HRM di UMKM. Metode pengambilan data dilakukan dengan menggunakan kuisioner dengan skala perbandingan, interview dan observasi lapangan. Teknik analisis data dilakukan dengan menggunakan analytical hierarchy process (AHP). Hasil penelitian menunjukkan bahwa implementasi green HRM pada UMKM dilakukan secara terorganisir mulai dari proses rekriutmen, seleksi, pelatihan dan pengembangan, performance evaluation, penghargaan, job diskripsi tenaga kerja dan pengelolaan tenaga kerja yang didasarkan pada konsep green. Diantara proses tersebut, proses pelatihan dan pengembangan mempunyai bobot tertinggi yang menunjukkan sebagai proses terpenting dalam implementasi green HRM di UMKM.
\end{abstract}

Kata kunci: UMKM, Green, Human Resource Management (HRM), AHP, pelatihan dan pengembangan.

\section{ABSTRACT}

SM Es are an important economic element for the growth of the people's economy, and it is one type of business that can absorb a lot of labor because of its labor-intensive nature. However, on the other hand the level of awareness of MSMEs on environmental management needs to be increased. This is the background of the importance of implementing green human resource management (green HRM) on SMEs. This study aims to determine the priority of green HRM criteria on SMEs and the formulation of strategic steps in the optimization of green HRM in SMEs. Method of data retrieval was done by using questionnaire with comparison scale, interview and field observation. Data analysis technique is done by using analytical hierarchy process (AHP). The results show that the implementation of green HRM at SMEs is done in an organized manner starting from recruitment, selection, training and development process, performance evaluation, award, job description job and labor management based on green concept. Among these processes, the training and development process has the highest weights that show as the most important process in the implementation of green HRM in SMEs.

Keywords: SMEs, Green, Human Resource Management (HRM), AHP, training and development.

\section{PENDAHULUAN}

Usaha Mikro, Kecil dan Mengengah (UMKM) merupakan sektor perekonomian yang mempunyai peran penting bagi pertumbuhan perekonomian di Indonesia. Berdasarkan data Kementrian Koperasi dan Usaha Kecil dan Menengah tahun 2013, menunjukkan bahwa 99,99 persen unit usaha di Indonesia merupakan UMKM dan 0,01 persen merupakan usaha besar, tingkat penyerapan tenaga kerja mencapai 97,16 persen, dan berkontribusi sebesar 59,08 persen pada PDB, kontribusi terhadap total eksport mencapai 14,06 persen. Sementara di Portugal, UMKM mampu memberikan kontribusi sebesar 59,8 persen pada pendapatan negara (Santos et al., 2013). Lebih dari itu, keberadaan UMKM mampu mengurangi jumlah pengangguran dan telah terbukti kokoh dalam menghadapi krisis ekonomi tahun 1998.

UKM didefinisikan oleh Badan Pusat Statistik (BPS) sebagai perusahaan dengan jumlah tenaga kerja antara 5 sampai 19 karyawan (BPS, 1997). Perusahaan dengan kurang dari 5 karyawan disebut 
home industry. Menurut Kurilof dalam Pasaribu (2005), untuk menjamin keberlangsungan hidup UMKM, maka pelaku UMKM memiliki empat kemampuan yang seimbang, yaitu: (1) Technical competence, yaitu memiliki kompetensi dalam bidang rancang bangun (know-how) sesuai dengan usaha yang akan dipilih. (2) Marketing competence, yaitu memiliki kompetensi dalam menemukan pasar yang cocok, mengidentifikasi pelanggan dan menjaga kelangsungan hidup perusahaan. (3) Financial competence, yaitu memiliki kompetensi dalam bidang keuangan, mengatur pembelian, penjualan, pembukuan, dan penghitungan laba/rugi. (4) Human relation competence, yaitu kompetensi dalam mengembangkan hubungan personal, seperti kemampuan berelasi dan menjalin kemitraan antarperusahaan.

Berdsarakan sisi potensi pengembangan, UMKM merupakan sektor ekonomi yang berpotensi untuk dikembangan ke ranah internasional. Berbagai macam produk UMKM layak digunakan sebagai produk unggulan ekspor, tetapi dalam perkembangannya, terdapat hambatan dalam menjangkau pasar ekspor, antara lain kebijakan domestik dan kurangnya informasi tentang berbagai kebutuhan dipasar ekspor sehingga diperlukan kebijakan dan strategi untuk mengatasi hal ini (Cardoza et al., 2016).

Salah satu karakteristik kuat pada UMKM adalah bersifat padat karya, menggunakan teknologi yang sederhana dan mudah dipahami serta mampu menjadi tempat masyarakat untuk bekerja (Anggraeni et al., 2013). Besarnya tingkat penggunaan tenaga kerja di UMKM, mengakibatkan peran tenaga kerja sangat penting bagi UMKM. Tenaga kerja bukan lagi sebagai pekerja, tetapi telah menjadi suatu modal usaha bagi UMKM (human capital). Selain itu, hasil penelitian penulis menunjukkan adanya hubungan positif antara tenaga kerja dengan produktivitas UMKM tetapi peran tenaga kerja pada peningkatan produktivitas UMKM masih rendah (Astuti et al., 2013). Oleh karena itu, perlu peningkatan peran tenaga kerja UMKM dalam rangka meningkatkan produktivitas UMKM.

Isu lingkungan disisi lain menjadi faktor penting bagi perkembangan UMKM. Perusahaan, dalam skala mikro, kecil dan menengah serta besar memberikan kontribusi terjadinya masalah lingkungan, dengan adanya polusi limbah gas, cair dan padat, sehingga perusahaan wajib ikut serta dalam menyelesaikan masalah lingkungan (Agan $e t$ al., 2013). Oleh karena itu, untuk menjamin keberlanjutan usaha, maka perlu memperkenalkan aspek lingkungan dan sosial dalam kerangka bisnis (Kondoh et al., 2014). Pengelolaan lingkungan pada proses operasional usaha (UMKM), memberikan pengaruh positif pada keberlanjutan UMKM dalam jangka pendek dan jangka panjang (Zeng et al., 2011).

Tenaga kerja sebagai pelaku utama UMKM perlu memahami pengelolaan lingkungan sebagai salah satu aspek dalam rangka meningkatkan produktivitas usaha. Green human resource management (Green HRM) merupakan salah satu alat yang dapat digunakan untuk mengelola tenaga kerja UMKM dengan melibatkan aspek lingkungan. Saat ini, pengelolaan tenaga kerja UMKM belum melibatkan aspek lingkungan, masih berfokus pada kompetensi tenaga kerja (Ardiana dan Subaedi, 2010), pengukuran kinerja UMKM (Lin dan Lin, 2016) dan inovasi pada UMKM (Gu et al., 2015).

Green HRM merupakan suatu sistem pengelolaan tenaga kerja yang diterapkan untuk mengurangi dampak negatif terhadap lingkungan atau meningkatkan dampak positif lingkungan terhadap kinerja UMKM secara berkelanjutan (Arulrajah et al., 2015). Green human resource management merupakan pengembangan dari human resource management (HRM) yang $\mathrm{di}$ Indonesia dikenal dengan manajemen sumber daya manusia, yaitu: suatu kebijakan dan praktik yang dibutuhkan seseorang yang menjalankan aspek orang atau perekrutan, penyaringan, pelatihan, pengimbalan, dan penilaian (Desler dalam Tiffani, 2013). HRM merupakan aspek paling penting dalam pengelolaan usaha, melalui pendekatan yang inovatif sehingga mampu meningkatkan perekonomian, teknologi, sosial budaya dan lingkungan perusahaan (Cech et al., 2016). Lebih dari itu, adanya tuntutan ekonomi, globalisasi, keragaman dalam negeri dan teknologi maka mendorong perusahaan untuk melakukan berbagai perkembangan pengelolaan dalam bidang sumber daya manusia perusahaan (Stone dan Deadrick, 2015). Tetapi, disisi lain, seringkali pengembangan sumber daya manusia dalam perusahaan menjadi prioritas kedua setelah pengembangan teknologi dalam bentuk hardware. Hasil penelitian penulis menunjukkan bahwa aspek sumber daya manusia mempunyai tingkat kepentingan yang lebih rendah jika dibandingkan dengan teknologi (technoware) dalam proses adopsi teknologi pada UMKM (Wahyuni et al., 2015).

Salah satu bentuk perkembangan dalam bidang HRM adalah dengan menambahkan unsur lingkungan hidup yang selanjutnya dikenal dengan green HRM, yaitu memfasilitasi keterlibatan karyawan dalam pengelolaan lingkungan, diwujudkan 
dalam bentuk komitmen bersama untuk melakukan perubahan tindakan dalam rangka mendukung organisasi dalam usaha melaksanakan pengelolaan (perlindungan) lingkungan (Pinzone et al., 2016). Green HRM difokuskan pada perencanaan sistemik terkait dengan praktek manajemen sumber daya manusia yang sesuai dengan tujuan organisasi dalam pengelolaan lingkungan (Millar et al., 2016).

Implementasi green HRM merupakan salah satu bentuk usaha peningkatan produktivitas dan komitmen perusahaan (UMKM) dalam menjaga keberlanjutan lingkungan hidup. Beberapa bentuk implementasi green HRM pada perusahaan dilaksanakan melalui manajemen kinerja, pelatihan, pengembangan, dan pembelajaran, kompensasi dan manfaat serta budaya organisasi (Jackson et al., 2011). Lebih dari itu, penerapan green HRM membutuhkan komitmen kuat dari manajemen dilevel atas, melalui suatu bentuk perencanaan yang komprehensif sebagai pedoman oleh karyawan dilevel operasional (Fayyazi et al., 2015). Dengan adanya hal tersebut, maka implementasi green HRM akan memberikan beberapa keuntungan bagi peusahaan antara lain: (1) perbaikan dalam proses retensi karyawan, (2) memperbaiki nama perusahaan di khalayak umum, (3) memperoleh karyawan yang lebih baik, (4) meningkatkan produktivitas dan keberlanjutan perusahaan, (5) mengurangi pengaruh lingkungan yang ditimbulkan oleh perusahaan, (6) memperbaiki daya saing dan meningkatkan keseluruhan kinerja perusahaan (Cherian dan Jacob, 2012).

Berdasarkan uraian tersebut, terlihat bahwa green HRM penting untuk diterapkan pada UMKM. Tetapi dalam implementasinya, perlu beberapa strategi agar proses implementasi green HRM pada UMKM dapat memberikan hasil yang optimal. Salah satu strategi yang dapat digunakan adalah dengan menentukan prioritas kriteria-kriteria green HRM pada UMKM berdasarkan tingkat kepentingannya. Oleh karena itu, penelitian ini bertujuan untuk menentukan prioritas kriteria-kriteria green HRM pada UMKM. Diharapkan dengan diketahuinya kriteria green HRM di UMKM dan tingkat kepentingan untuk setiap kriteria tersebut, maka dapat dirumuskan langkah strategis dalam optimalisasi green HRM di UMKM.

\section{METODE PENELITIAN}

Obyek penelitian yang digunakan adalah UMKM pangan di wilayah Kabupaten Sidoarjo, dengan sampel penelitian adalah UMKM dengan syarat mempunyai tenaga kerja minimal 10 orang.
Metode pengambilan data yang digunakan adalah wawancara yang dilakukan untuk memperoleh informasi sejauh mana adopsi teknologi telah dilakukan oleh UMKM jika dihubungkan dengan model hasil penelitian tahun pertama. Wawancara akan dilakukan pada pengelola UMKM, akademisi dan Pemerintah daerah yang memegang kebijakan terkait dengan pengembangan UMKM. Focus Group Discussion (FGD) yang dilakukan sebagai media diskusi antara peneliti, pelaku UMKM, akademisi, dan Pemerintah daerah yang bertujuan untuk menggali pendapat tentang kesesuaian model hasil penelitian tahun pertama. Kuisioner yang digunakan sebagai alat untuk mengetahui tingkat kepentingan masing- masing kriteria pada green HRM. Responden responden merupakan tenaga yang ekspert dalam implementasi green HRM, yaitu akademisi yang memahami konsep green HRM

Teknik pengolahan data dilakukan dengan menggunakan metode AHP (Analytical Hierarchy Process). AHP merupakan salah satu penentuan metode pengambilan keputusan berdasarkan bobot masing- masing kriteria yang dikembangkan oleh Thomas L Saaty pada tahun 1988 (Susihono, 2013). AHP dilakukan dengan menyusun hirarki dari berbagai permasalahan yang komplek/ multi faktor sehingga permasalahan akan terlihat lebih terstruktur dan sistematis (Darmanto et al., 2014). AHP telah banyak digunakan dalam berbagai bidang kajian, antara lain bobot penilaian untuk penentuan prioritas komponen teknologi (Cahyono dan Wahyuni, 2015), dan prioritas dalam penentuan lokasi (Erbiyik et al., 2012).

Perhitungan AHP dilakukan dengan langkahlangkah yang diawali dengan merumuskan $\mathrm{C}=\{\mathrm{Cj} /$ $\mathrm{j}=1,2, \ldots \mathrm{n}\}$ kriteria. Dimana skala perbandingan (pairwaise comparison) untuk $\mathrm{n}$ kriteria disusun dalam suatu matrik $A(n x n)$ dengan $a_{i j}(i, j=1,2, \ldots n)$ merupakan bobot setiap. Selanjutnya, masing masing matrik dinormalisasi untuk menemukan bobot relatif, yang disebut dengan eigenvactor (w) dan berhubungan dengan eigenvalue $\left(\lambda_{\text {mak }}\right)$ melalui persamaan berikut:

$$
A_{w}=\lambda_{\text {max }} \cdot \mathrm{w}
$$

Jawaban yang semakin konsisten, nilai $1_{\text {mak }}$ cenderung mendekati n. Saaty (1980) telah mengembangkan suatu indeks konsistensi untuk untuk mengukur konsistensi judgment saat melakukan perbandingan dengan merumuskan indeks konsistensi (CI) sebagai : 
$C I=\frac{\lambda_{\text {mak }}-n}{(n-1)}$

Indeks $\mathrm{CI}=0$ mencerminkan "pairwise comparision" dari judgement konsistent sempurna. Kemudian dikembangkan indeks CR (Consistency Ratio Indeks) yang didefiniskan sebagai perbandingan CI untuk suatu judgment tertentu dengan CI dari "random judgement". Saaty telah menyarankan bahwa sebaiknya CR dibawah $10 \%$ $(0,1)$ untuk menunjukkan bahwa "value judgement" yang diberikan dapat diterima, dan kalau sebaliknya memerlukan revisi atau peninjauan kembali.

\section{HASIL DAN PEMBAHASAN}

Perumusan kriteria yang digunakan untuk menyusun strategi implementasi green HRM didasarkan aspek rekruitmen karyawan, seleksi karyawan, pelatihan dan pengembangan karyawan, performance evaluation, penghargaan, desain dan analisis job diskripsi yang mengandung unsur green, perencanaan green HRM (Jabbaur \& Jabbaur, 2016).

Pengambilan data dilakukan dengan menggunakan kuisioner berdasarkan skala perbandingan dengan ketentuan sebagai berikut:

Tabel 1. Skala perbandingan

\begin{tabular}{|c|c|c|}
\hline $\begin{array}{l}\text { Intensitas } \\
\text { Kepentingan }\end{array}$ & Definisi & Keterangan \\
\hline 1 & Kepentingan sama & $\begin{array}{l}\text { Dua aktivitas memberikan kontribusi yang } \\
\text { sama terhadap sebuah tujuan }\end{array}$ \\
\hline 3 & $\begin{array}{llr}\text { Salah } & \text { satu lebih } \\
\text { penting } & \text { dibandingkan } \\
\text { lainnya } & \\
\end{array}$ & $\begin{array}{l}\text { Suatu kegiatan lebih penting dibandingkan } \\
\text { aktivitas lainnya, tetapi kelebihan tersebut } \\
\text { kurang meyakinkan atau tidak signifikan }\end{array}$ \\
\hline 5 & $\begin{array}{l}\text { Mempunyai } \\
\text { kepentingan } \\
\text { esensial }\end{array}$ & $\begin{array}{l}\text { Terdapat bukti yang bagus dan kriteria yang } \\
\text { logis yang menyatakan bahwa salah satu } \\
\text { kegiatan memang lebih penting daripada } \\
\text { kegiatan lainnya }\end{array}$ \\
\hline 7 & $\begin{array}{l}\text { Kepentingan } \\
\text { ditonjolkan }\end{array}$ & $\begin{array}{l}\text { Salah satu kegiatan lebih penting } \\
\text { dibandingkan aktivitas lainnya apabila dapat } \\
\text { dibuktikan secara meyakinkan }\end{array}$ \\
\hline 9 & $\begin{array}{l}\text { Memiliki kepentingan } \\
\text { yang absolut }\end{array}$ & $\begin{array}{l}\text { Suatu kegiatan secara tegas memiliki } \\
\text { kepentingan yang paling tinggi }\end{array}$ \\
\hline $2,4,6,8$ & $\begin{array}{l}\text { Nilai diantara dua } \\
\text { kepentingan }\end{array}$ & $\begin{array}{l}\text { Dibutuhkan kesepakatan untuk menentukan } \\
\text { tingkat kepentingannya }\end{array}$ \\
\hline
\end{tabular}

Sumber : ESCAP (1988b : 56)

Kuisioner disebarkan kepada dua orang yang expert dalam hal green HRM, dengan kriteria dan sub kriteria terlihat pada Tabel 2 dan Perhitungan dengan menggunakan langkah-langkah AHP ditunjukkan dalam Tabel 3.

Hasil penelitian yang disajikan pada Tabel 3 dan Tabel 4 yang menunjukkan bobot prioritas sub kriteria di masing masing kriteria, terlihat adanya bobot paling tinggi diantara sub kriteria lainnya. Bobot tertinggi tersebut menunjukkan bahwa sub kriteria tersebut lebih penting dari sub kriteria lainnya.

Kriteria rekrutmen, bobot tertinggi terdapat pada sub kriteria R3, yaitu mengkomunikasikan kebijakan/ komitmen perusahaan terhadap kelestarian lingkungan pada saat proses rekrutmen. Kriteria seleksi, bobot tertinggi pada sub kriteria S2, yaitu mengajukan pertanyaan terkait pengelolaan lingkungan pada saat wawancara dengan calon karyawan. Bobot tertinggi pada kriteria pelatihan dan pengembangan terdapat pada sub kriteria mengembangkan ketrampilan dan pengetahuan karyawan tentang pengelolaan lingkungan melalui pelatihan (PP1) dan memberikan best practice tentang kegiatan yang ramah lingkungan (PP2).

Kriteria performance evaluation, bobot tertinggi terdapat pada sub kriteria menguasi standar kinerja lingkungan secara keseluruhan. Untuk kriteria penghargaan, bobot tertinggi terdapat pada sub kriteria memberikan penghargaan finansial dan non finansial untuk karyawan yang mempunyai kinerja lingkungan dengan baik.

Kriteria green jon desaign dan analysis, bobot tertinggi terdapat pada sub kriteria membentuk tim lintas departemen untuk mengelola masalah lingkungan perusahaan. Pada kriteria green HRM, terlihat bahwa 2 sub kriteria mempunyai bobot yang sama yaitu memasukkan unsur jumlah karyawan dan jenis karyawan untuk menerapkan program kegiatan 


\section{Tabel 2. Kriteria green HRM}

\begin{tabular}{|c|c|}
\hline Kriteria & Sub Kriteria \\
\hline Rekrutmen (R) & $\begin{array}{l}\text { 1. Memasukkan unsur lingkungan pada startegi rekrutmen perusahaan (R1). } \\
\text { 2. Memasukkan unsur lingkungan sebagai salah satu kriteria rekrutmen (R2) } \\
\text { 3. Mengkomunikasikan kebijakan/ komitmen perusahaan terhadap } \\
\text { kelestarian lingkungan pada saat proses rekrutmen (R3). } \\
\text { 4. Memasukkan unsur pengetahuan tentang lingkungan pada iklan pekerjaan } \\
\text { (R4). } \\
\text { 5. Menginformasikan bahwa perusahaan akan merektrut calon karyawan } \\
\text { yang memiliki kompetensi pengelolaan lingkungan (R5). }\end{array}$ \\
\hline Seleksi (S) & $\begin{array}{l}\text { 1. Mempertimbangkan kandidat yang mempunyai minat dan kepedulian pada } \\
\text { lingkungan (S1). } \\
\text { 2. Mengajukan pertanyaan terkait pengelolaan lingkungan pada saat } \\
\text { wawancara dengan calon karyawan (S2). } \\
\text { 3. Memilih calon karyawan yang sadar terhadap pengelolaan lingkungan } \\
\text { (S3). } \\
\text { 4. Memilih calon karyawan yang secara pribadi telah melakukan pengelolaan } \\
\text { lingkungan (S4). }\end{array}$ \\
\hline $\begin{array}{l}\text { Pelatihan dan } \\
\text { pengembangan } \\
\text { (PP) }\end{array}$ & $\begin{array}{l}\text { 1. Mengembangkan ketrampilan dan pengetahuan karyawan tentang } \\
\text { pengelolaan lingkungan melalui pelatihan (PP1) } \\
\text { 2. Memberikan best practice tentang kegiatan yang ramah lingkungan (PP2). } \\
\text { 3. Memberikan pelatihan untuk meningkatkan kesadaran lingkungan di } \\
\text { setiap angkatan kerja (departemen kerja) (PP3). } \\
\text { 4. Menyediakan program pendidikan tentang lingkungan untuk karyawan } \\
\text { (PP4). } \\
\text { 5. Memberikan pelatihan kepada karyawan agar dapat menjadikan ruang } \\
\text { kerja sebagai ruang hijau (PP5). } \\
\text { 6. Menerapkan rotasi pekerjaan untuk melatih manajer dalam memahami } \\
\text { lingkungan (PP6). } \\
\text { 7. Memberikan pelatihan khusus untuk kegiatan penghijauan bagi karyawan } \\
\text { (PP7). } \\
\text { 8. Melakukan analisis kebutuhan untuk mendefinisikan jenis pelatihan yang } \\
\text { diperlukan dalam rangka penghijauan (PP8). } \\
\text { 9. Melakukan analisis dan identifikasi kebutuhan pelatihan yang mampu } \\
\text { meningkatkan kesadaran karyawan ke lingkungan (PP9). } \\
\text { 10. Memberikan kesempatan pada semua orang diperusahaan untuk dilatih } \\
\text { mengenai aspek pengelolaan lingkungan (PP10) }\end{array}$ \\
\hline $\begin{array}{l}\text { Performance } \\
\text { evaluation }(\mathrm{PE})\end{array}$ & $\begin{array}{l}\text { 1. Menetapkan sistem informasi pengelolaan lingkungan (EMIS) dan audit } \\
\text { lingkungan (PE1). } \\
\text { 2. Menintegrasikan tujuan dan target pengelolaan lingkungan pada sistem } \\
\text { evaluasi kinerja perusahaan (PE2). } \\
\text { 3. Menguasi standar kinerja lingkungan secara keseluruhan (PE3) } \\
\text { 4. Mengintegrasikan unsur kinerja lingkungan pada penilaian kinerja } \\
\text { karyawan (PE4). } \\
\text { 5. Menetapkan sasaran, target dan tanggungjawab lingkungan (PE5) } \\
\text { 6. Memberikan umpan balik kepada karyawan tentang kinerja lingkungan } \\
\text { untuk memperbaiki kinerja karyawan (PE6). } \\
\text { 7. Melakukan evaluasi/ pengukuran tentang kinerja lingkungan untuk setiap } \\
\text { karyawan (PE7). }\end{array}$ \\
\hline Penghar & $\begin{array}{l}\text { 1. Menghargai kinerja lingkungan karyawan (bagus, kurang bagus atau } \\
\text { sangat bagus (P1). } \\
\text { 2. Memberikan penghargaan finansial dan non financial untuk karyawan } \\
\text { yang mempunyai kinerja lingkungan dengan baik (P2). } \\
\text { 3. Mengokumunikasikan atau mensosialisasikan keunggulan lingkungan } \\
\text { yang dihasilkan karyawan (P3). } \\
\text { 4. Memberikan insentif untuk karyawan yang berperilaku ramah lingkungan }\end{array}$ \\
\hline
\end{tabular}


Tabel 3. Hasil Pembobotan antar sub kriteria green HRM

\begin{tabular}{|c|c|c|}
\hline Kriteria & Sub kriteria & Bobot Prioritas \\
\hline \multirow[t]{5}{*}{$\mathrm{R}$} & $\mathrm{R} 1$ & 0,19 \\
\hline & $\mathrm{R} 2$ & 0,31 \\
\hline & R3 & $0,38 *$ \\
\hline & $\mathrm{R} 4$ & 0,06 \\
\hline & $\mathrm{R} 5$ & 0,06 \\
\hline \multirow[t]{4}{*}{$S$} & $\mathrm{~S} 1$ & 0,20 \\
\hline & $\mathrm{S} 2$ & $0,64 *$ \\
\hline & S3 & 0,08 \\
\hline & $\mathrm{S} 4$ & 0,08 \\
\hline \multirow[t]{10}{*}{$\mathrm{PP}$} & PP1 & $0,18^{*}$ \\
\hline & PP2 & $0,18^{*}$ \\
\hline & PP3 & 0,16 \\
\hline & PP4 & 0,03 \\
\hline & PP5 & 0,09 \\
\hline & PP6 & 0,05 \\
\hline & PP7 & 0,07 \\
\hline & PP8 & 0,09 \\
\hline & PP9 & 0,07 \\
\hline & PP10 & 0,07 \\
\hline \multirow[t]{7}{*}{$\mathrm{PE}$} & PE1 & 0,12 \\
\hline & PE2 & 0,05 \\
\hline & PE3 & $0,42 *$ \\
\hline & PE4 & 0,08 \\
\hline & PE5 & 0,19 \\
\hline & PE6 & 0,06 \\
\hline & PE7 & 0,08 \\
\hline \multirow[t]{4}{*}{$\mathrm{P}$} & $\mathrm{P} 1$ & 0,13 \\
\hline & $\mathrm{P} 2$ & $0,45^{*}$ \\
\hline & P3 & 0,27 \\
\hline & $\mathrm{P} 4$ & 0,16 \\
\hline \multirow[t]{4}{*}{$\mathrm{G}$} & G1 & 0,21 \\
\hline & $\mathrm{G} 2$ & $0,61 *$ \\
\hline & G3 & 0,11 \\
\hline & G4 & 0,07 \\
\hline \multirow[t]{2}{*}{ GH } & GH1 & $0,5^{*}$ \\
\hline & $\mathrm{GH} 2$ & $0,5^{*}$ \\
\hline
\end{tabular}

Tabel 4. Hasil pembobotan antar kriteria

\begin{tabular}{ll}
\hline Kriteria & Bobot Prioritas \\
\hline R & 0,04 \\
S & 0,12 \\
PP & $0,26^{*}$ \\
PE & 0,24 \\
P & 0,08 \\
G & 0,13 \\
GH & 0,13 \\
\hline
\end{tabular}

*bobot tertinggi disetiap kriteria

pengelolaan lingkungan perusahaan serta menyusun strategi untuk mengelola lingkungan, misalnya melalui pelaksanaan audit lingkungan oleh tenaga ahli.

Untuk perbandingan antar kriteria, yang disajikan pada Tabel 4, terlihat bahwa dari 7 kriteria green HRM yang ditentukan, maka bobot tertinggi terdapat pada kriteria pelatihan dan pengembangan. Bobot tertinggi menunjukkan tingkat prioritas dalam implementasi green HRM di lapangan.

Berdasarkan hasil tersebut, maka proses implementasi green HRM pada UMKM dapat dirumuskan dengan memfokuskan pada nilai tertinggi di setiap kriteria. Strategi implementasi disusun didasarkan prioritas tersebut. Pada tahap ini, strategi disusun berdasarkan kriteria green HRM, yaitu: (1) Strategi rekruitmen: pihak UMKM menyusun kebijakan/ komitmen bahwa UMKM akan mengimplementasikan konsep green HRM pada proses operasionalnya. Kebijakan atau komitmen ini dilanjutkan dengan memasukkan pertimbangan konsep green pada proses rekruitmen calon tenaga 
kerjaa. (2) Strategi seleksi: menjadikan tingkat pemahaman konsep green pada proses seleksi dan pengambilan keputusan penerimaan tenaga kerja. (3) Strategi pada pelatihan dan pengembangan dilakukan dengan memberikan pelatihan dan melakukan studi banding kepada tenaga kerja UMKM dalam hal green HRM. Hal ini bertujuan untuk memberikan gambaran terkait dengan dampak posistif implementasi green HRM pada keberlanjutan usaha. (4) Strategi performance evaluation dilakukan dengan memasukkan unsur green pada proses evaluasi kinerja UMKM.

Strategi penghargaan dilaksanakan dengan merancang penghargaan dalam bentuk finansial untuk tenaga kerja UMKM yang telah memberikan inovasi dalam pengelolaan lingkungan usaha. Strategi green job desaign dan analysis dilaksanakan dengan memasukkan unsur green pada setiap job diskripsi masing- masing karyawan. Strategi green HRM dilaksanakan dengan mempertimbangkan besarnya jumlah karyawan dalam menentukkan bentuk kegiatan yang mengarah pada implementasi green HRM.

Strategi- strategi tersebut dapat digunakan sebagai langkah strategi bagi UMKM yang akan mengimplementasikan konsep green pada usahanya. Berdasarkan hasil observasi di lapangan, terlihat bahwa sampai saat ini tingkat pemahaman UMKM pada implementasi konsep green HRM perlu ditingkatkan, meskipun sebagian besar UMKM telah melakukan berbagai usaha dalam pengelolaan lingkungan, misalnya dengan pengolahan limbah padat dan cair, melakukan penghijauan di lokasi sekitar usaha, tetapi proses tersebut dilakukan di tengah proses operasional. Artinya, konsep green belum dilakukan secara terintegrasi dengan proses pengelolaan tenaga kerja mulai dari rekruitmen.

\section{SIMPULAN DAN SARAN}

Hasil penelitian menunjukkan bahwa implementasi green HRM perlu diimplementasikan pada UMKM. Hal ini didukung dengan adanya peran UMKM yang sangat penting bagi perkembangan ekonomi negara dan karakteristik UMKM yang bersifat padat karya. Implementasi green HRM pada UMKM dilakukan secara terorganisir mulai dari proses rekrutmen, seleksi, pelatihan dan pengembangan, performance evaluation, penghargaan, job diskripsi tenaga kerja dan pengelolaan tenaga kerja yang didasarkan pada konsep green. Proses implementasi green HRM perlu diawali dengan adanya kebijakan/ komitmen yang kuat dari pemilik UMKM untuk mengimplementasikan konsep tersebut.
Penelitian ini dibatasi pada perumusan strategi implementasi, belum mampu menggambarkan sejauh mana dampak yang dihasilkan oleh implementasi green HRM pada kinerja perusahaan. Peneliti selanjutnya dapat diarahkan untuk mengetahui dampak yang dihasilkan dari implementasi green HRM pada kinerja perusahaan untuk memberikan motivasi kepada pelaku UMKM dalam implementasi konsep tersebut.

\section{REFERENSI}

Agan, Y., and Acar M.F. Borodin A. 2013. Drivers of environmental processes and their impact on performance: a study of Turkish SMEs, Journal Of Cleaner Production 51, 23-33.

Aridiana. Brahmayanti. Subaedi. 2010. Kompetensi SDM UKM dan Pengaruhnya Terhadap Kinerja UKM Di Surabaya, Jurnal Manajemen dan Kewirausahaan, 12(1), 4255.

Arulrajah A.A., Opatha H. Nawaratne N.N.J. 2015. Green Human Resource Management Practices: A Review, Sri lankan Journal of Human Resources Management, 5(1).

Anggraeni F.D. dan Hardjanto I. Hayat A. 2010. Pengembangan Usaha Mikro, Kecil dan Menengah (UMKM) Melalui Fasilitasi Pihak Eksternal dan Potensi Internal, Jurnal Administrasi Publik (JAP). 6, 1286-1295.

Astuti M. Wahyuni H.C. Sulistiyowati W., Ciptomulyono U., Kartiningsih P.D., 2013, Peningkatan Produktivitas Usaha Kecil dan Menengah (UKM) berbasis Technology Content Untuk Mendukung Pelaksanaan MP3EI 2011-2025, Proceding Seminar Nasional Fakultas Ekonomi, Universitas Muhammadiyah Sidoarjo, ISBN: 978-60298739-1-7.

Cahyono D.E. Wahyuni H.C. 2015. Penilaian Teknologi Menggunakan Analytical Hierarchy Process dan Teknometrik di Departemen Produksi. Jurnal Ilmiah Teknik Industri. (14) 2. 122-129.

Cardoza G. Fornes G. Farber V. Duarte G.R. Gutierrez J.R. 2016. Barriers and Public Policies Affecting The International Expansion of Latin American SMEs: Evidence from Brazil, Colombia, and Peru. Journal Of Business Research 69, 2030- 2039.

Cech M. Yao W. Samolejova A. Li J. Wicher P, 2016 Human Resource management in Chinese manufacturing companies, Perpectives In Science 7, pp 6-9. 
Cherian J. Jacob J. 2012. A Study of Green HR Practices and Its Effective Implementation in the Organization: A Review, International Journal Of Business And Management. (7) 21, 25-33.

Darmanto E. Latifah N. Susanti N. 2014. Penerapan Metode AHP (Analyic Hierarchy Process) Untuk Menentukan Kualitas Gula Tebu. Jurnal SIMETRIS. (5)1. 72-85.

Erbiyik H. Ozcan Z. Karaboga.K. 2012. Retail store location selection problem with multiple analytical hierarchy process of decision making an application in Turkey. Procedia - Social and Behavioral Sciences (58), pp 1405 - 1414.

Fayyazi M. Shahbazmoradi S. Afshar Z. Shahbazmoradi M.R. 2015, Investigating the barriers of the green human resource management implementation in oil industry, Management Science Letters 5, 101-108.

Gu Q. Jiang W. Wang G.G. 2016. Effects of external and internal sources on innovation performance in Chinese high-tech SMEs: A resource-based perspective, Journal Of Engineering dan Management Technology, Vol 40, 76- 86

Jackson S. Renwick D.W.S. Jabbour J.C.J. Camen M.M. 2011, State-of-the-Art and Future Directions for Green Human Resource Management: Introduction to the Special Issue, German Journal Of Research In Human Resource Management 25, 96-116.

Kondoh S. Komoto H. Kishita Y. Fukushige S. 2014. Toward a sustainable business design: a survey, Procedia CIRP 15, 367- 372.

Lin F.J, Lin Y.H, 2016, The effect of network relationship on the performance of SMEs, Journal Of Business Recearch 69, pp 17801784.

Millar J.H. Sanyal C. Camen M.M. 2011., Green human resource management: a comparative qualitative case study of a United States multinational corporation, The International
Journal Of Human Resource Management, Vol 27, No 2,192-211.

Pasaribu. 2005. Analisis Peningkatan Kompetensi Pengusaha Kecil Sesudah Mengikuti Pelatihan Kewirausahaan Yang Diselenggarakan Swisscontact Medan, Jurnal Sistem Teknik Industri. (6) 5. 49-52.

Pinzone M. Guerci M. Lettieri E. Redman T. 2016. Progressing in the change journey towards sustainability in healthcare: the role of 'Green' HRM, Journal Of Cleaner Production 122, 201-211.

Santos G. Ballros S. Mendes F. Lopes N. 2013. The Main Beneûts Associated With Health and Safety Management Systems Certiûcation In Portuguese Small and Medium Enterprises Post Quality Management System Certiûcation. Safety Science Journal 51. 29-36.

Susihono W.2013. Penilaian Teknologi Untuk Menentukan Posisi Industri Pesaing. Jurnal Teknik Industri. (7) 2, hal 131- 138.

Stone D.L. Deadrick D.L. 2015, Challenges and opportunities affecting the future of human resource management, Human Resource Management Review 25, pp 139- 145.

Tiffani B. Rustam. 2013. Audit Manajemen Untuk Menilai Efektifitas Fungsi Sumber Daya Manusia. Jurnal Ilmiah Mahasiswa FEB, Vol 1 No 1.

Wahyuni C.H. Hartati V. Astuti M 2015. Identifikasi Tingkat Adopsi Teknologi Untuk Meningkatkan Kualitas Produk Pada Industri Kecil Tahu Di Kabupaten Sidoarjo, Proseding Satelit, Universitas Brawijaya, Malang.

Zeng S.X, Meng X.H, Zeng R.C, Tam C.M, Tam W.Y, Jin T, 2011, How environmental management driving forces affect environmental and economic performance of SMEs: a study in the Northern China district, Journal of Cleaner Production 19, pp 1426- 1437. 